\title{
Optimization and evaluation of a domestic wastewater treatment system by dual combination of metallic salts and zeolites filtration
}

\author{
G. López-Ocaña ${ }^{1}$, R. G. Bautista-Margulis ${ }^{1}$, S. Méndez-Angulo ${ }^{1}$, \\ J. R. Hernández-Barajas ${ }^{1}$, C. A. Torres-Balcázar ${ }^{1}$, \\ R. M. Padrón-López ${ }^{1}$, E. de la Cruz-Luna ${ }^{2} \&$ M. I. Ferrer-Sánchez ${ }^{1}$ \\ ${ }^{1}$ Juarez Autonomous University of Tabasco, Mexico \\ ${ }^{2}$ The Polytechnic University of Centre, Tabasco, Mexico
}

\begin{abstract}
The implementation of smaller wastewater treatment plants is currently a trending topic in many countries of Latin America. This situation is rapidly growing since the influent characteristics have become very specific according to the domestic wastewater generators. In this context, the removal efficiency of a small domestic wastewater treatment system has been evaluated and improved by applying coagulation-flocculation techniques with zeolites filtration. For the coagulation-flocculation process, calcium hydroxide $\left[\mathrm{Ca}(\mathrm{OH})_{2}\right]$ and aluminum sulfate $\left[\mathrm{Al}_{2}\left(\mathrm{SO}_{4}\right)_{3}\right]$ were used to increase both the superficial rate and removal efficiency of the gravitational sedimentation. Treatability tests were carried out to evaluate the mixing time, time of flocculation process and sedimentation time. From the experimental results, the removal efficiencies $(\eta)$ for turbidity were found to be as follows: $\eta_{1}=54.03 \%$ when using only 60 ppm of $\mathrm{Al}_{2}\left(\mathrm{SO}_{4}\right)_{3}, \eta_{2}=$ $70.48 \%$ when adding only $100 \mathrm{ppm}$ of $\mathrm{Al}_{2}\left(\mathrm{SO}_{4}\right)_{3}, \eta_{3}=91.96 \%$ when adding $15 \mathrm{mg} / \mathrm{l}$ of $\mathrm{Ca}(\mathrm{OH})_{2}$ and $50 \mathrm{mg} / 1$ of $\mathrm{Al}_{2}\left(\mathrm{SO}_{4}\right)_{3}, \eta_{4}=95.26 \%$ when adding $10 \mathrm{mg} / \mathrm{l}$ of $\mathrm{Ca}(\mathrm{OH})_{2}$ and $35 \mathrm{mg} / \mathrm{l}$ of $\mathrm{Al}_{2}\left(\mathrm{SO}_{4}\right)_{3}$ in combination with zeolites. Hence, it can be concluded that the removal efficiency of a given domestic wastewater plant may be improved by adjusting the hydraulic retention time and optimizing the amount of metallic salts under given operating conditions.

Keywords: wastewater treatment, metallic salts, zeolites filtration, coagulationflocculation.
\end{abstract}




\section{Introduction}

The development and design of smaller wastewater treatment plants (WWTP) is urgently needed in Latin America due to specific characteristics of the wastewater generators. These new treatment systems should improve not only their removal efficiency but protect public health, avoid environmental degradation, reduce treatment costs and reuse effluents.

The current technological know-how of developed countries, established in Mexico and other cities of Latin America, lack of sufficient economical resources to be operated. Hence more appropriate options are still searching, that is, natural systems for wastewater treatments using renewable energy sources; while the conventional systems (activated sludge, biofilters, etc.) employ nonrenewable energy sources [1]. The latter have been preferably selected in industrialized countries with the objective of preventing pollution at the superficial water receptors and natural systems in developing countries. Likewise, wastewater for agricultural irrigation has been reused to protect its own resource [2].

The natural technologies for wastewater treatment can be generally divided into two main groups: 1) water systems applied on the ground and, 2) aquatic floating and rooted plants [3]. After the energy crisis in the 70s, the anaerobic technology has been increasingly applied to sustain the wastewater treatment. In tropical and subtropical regions, the right use of anaerobic reactors brought up the opportunity to remove organic matter from the influents [4]. Nevertheless, depending on the wastewater characteristics, a combination of two unit processes and operations is needed.

The most common employed technologies to treat wastewaters with domestic characteristics are: rotary mesh, activated sludge process, lagoon systems, artificial wetlands and soil treatment systems [1, 5]. However, other unit operations are usually applied like coagulation-flocculation, ionic exchange and neutralization by zeolites filtration. Generally, such treatment plants are designed depending on the chemical properties of the wastewater (e.g., organic matter, heavy metals, etc.). Furthermore, the main advantage of running these processes is its operating capacity to work discontinuously.

The objective of the present investigation was to evaluate and improve the removal efficiency of a pilot-scale wastewater treatment system by applying a dual combination of metallic salts with zeolites filtration. The operation of the wastewater treatment system was optimized with the minimum requirement amount of metallic salts under given water flow rate conditions. Also, a physicochemical analysis of the influent and effluent was determined during the operation of the wastewater system and compared to the Mexican environmental legislation [6]. 


\section{Materials and methods}

\subsection{Location of the pilot plant}

The field work was performed at the Academic Division of Biological Sciences (Dacbiol) - Juarez Autonomous University of Tabasco (UJAT) located in Villahermosa-Tabasco, Mexico. This is the only university for higher education in the state of Tabasco where physicochemical treatment systems have been installed. The acquisition of such systems was intended to treat a specific volume of wastewater generated in six academic areas within the university (as can be seen in Table 1).

Table 1: Location and volume capacity of the pilot plants at UJAT.

\begin{tabular}{lcc}
\hline Municipality & $\begin{array}{c}\text { Location of the } \\
\text { pilot plant }\end{array}$ & $\begin{array}{c}\text { Volume } \\
\text { capacity } \\
\text { (L/d) }\end{array}$ \\
\hline Centro & Sport training camp-Central unit & 20,000 \\
Centro & Bicentenary Park & 40,000 \\
Centro & Dacbiol-UJAT & 40,000 \\
Centro & Dacbiol-UJAT & 10,000 \\
Comalcalco & Multidisciplinary Division & 20,000 \\
Cunduacán & DAIA*-UJAT & 10,000 \\
\hline
\end{tabular}

*Academic Division of Engineering and Architecture.

The application of the Mexican environmental legislation [6] is compulsory at the Dacbiol-UJAT since it must comply with specific regulations for its handling, disposal and wastewater discharge. The pilot-scale wastewater plant was installed and operated since 2005. The implementation was made in order to solve the problem of continuous pollution in superficial water receptors, water underground, aquatic flora and fauna. At present, the student population has considerably increased as to consider the evaluation of its hydraulic and removal efficiency. Previous experimental work has confirmed such increase of wastewater flow rates and contamination levels according to the current environmental regulation $[7,11]$. At that time, the wastewater flow rate of $120 \mathrm{~m}^{3} / \mathrm{d}$ was found to be continuously operating in the pilot-plant for $12 \mathrm{hr}$, exceeding its maximum capacity of $40 \mathrm{~m}^{3} / \mathrm{d}$.

\subsection{Hydraulic retention time (HRT) and sampling methods}

The unit processes were first identified to find out any technical deficiency in the treatment system. The wastewater sampling was carried out according to the specifications of the Mexican technical norms [1]. This environmental regulation indicates whether the discharge, coming from the generator process, operates in the range of 18 and 24 hours. The number of single samples should be six as a minimum, with a time interval between 3 and 4 hours. As illustrated in Figure 1, the sampling points along the system were as follows: 1) storage tank, 2) the calcium hydroxide tank, 3) the aluminum sulfate tank, 4) the inlet sedimentation 
channeling, 5) the outlet sedimentation channeling, 6) the inlet filter, 7) the outlet filter, and 8) the final discharge. The discharge capacity was measured by the direct method and the velocity section [8].The hydraulic evaluation of the system consisted, firstly, in determining its hydraulic retention time (HRT) and, secondly, the water velocity in the conducting lines. The HRT calculation was made by following the design criteria [7].

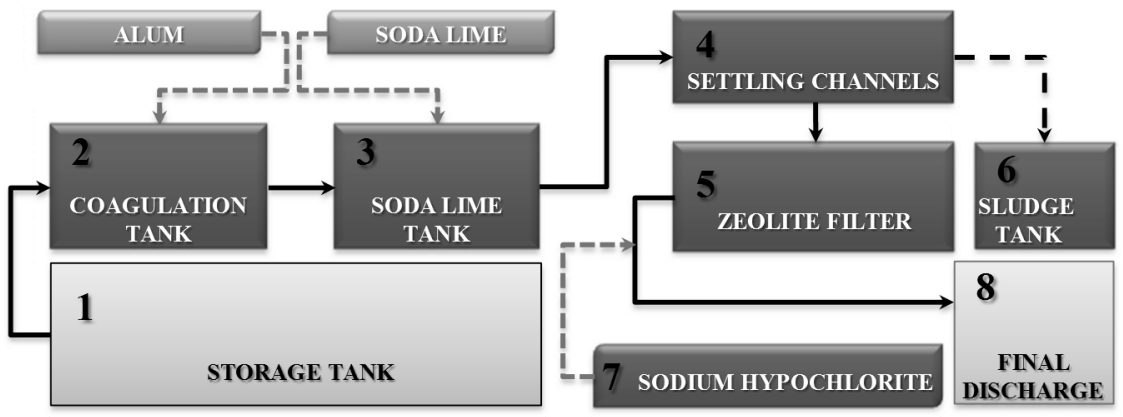

Figure 1: $\quad$ Flow diagram of the WWTP.

\subsection{Wastewater composition analysis}

The physicochemical characterization of the wastewater was undertaken following the analytical procedures established in the above mentioned environmental regulation. During the monitoring, the influent and effluent were sampled daily to evaluate the efficiency of the treatment system. The samples were analyzed immediately, following the methods and the calibration guidelines suggested by Hach Company [10]. The control parameters of the evaluated process were: $\mathrm{pH}$, temperature, total dissolved solids (TDS), color and turbidity. At the end of each evaluation, all the parameters were again analyzed and compared with the environmental normativity. The pilot plant was operated at room temperature. For the optimization of the system, the right dosification of the metallic salts was constantly verified. To achieve it, various coagulationflocculation treatability tests were realized by means of the jar test method. These tests allowed us to evaluate the control parameters as a function of the mixing time, time of flocculate formation and sedimentation time.

\subsection{Performance of the pilot plant}

The pilot plant performance was evaluated based on the differences in influent and effluent concentrations. The control parameter was turbidity for the numerical calculation. The removal efficiency was calculated using the following formula:

$$
\eta=\left(\frac{C_{\text {influent }}-C_{\text {effluent }}}{C_{\text {influent }}}\right) \times 100
$$


where $\eta$ represents the percent removal efficiency and $\mathrm{C}$ the concentration of the measured variable.

Besides, the effluent quality was assessed based on the official permissible levels for different components in wastewater, in order to establish whether treated wastewater from the pilot plant can be used for irrigation purposes without causing harm to crops and soils.

\section{Results and discussion}

The wastewater flow rate of the pilot plant was recorded for eight months at the Dacbiol-UJAT. Such wastewater flow rates were found to be as $\mathrm{Q}_{1}=0.4 \mathrm{~L} / \mathrm{s}$ (minimum flow rate), $\mathrm{Q}_{2}=2.2 \mathrm{~L} / \mathrm{s}$ (middle flow rate) and $\mathrm{Q}_{3}=6.7 \mathrm{~L} / \mathrm{s}$ (maximum flow rate). It is worth mentioning that the plant does not have a regular operating timetable since its operation vary because of the user's availability. The start-up of the pilot plant is usually initiated between 7:00 and 10:00 hours, while the shutdown occurs between 16:00 and 19:00 hours (Figures 2-4).

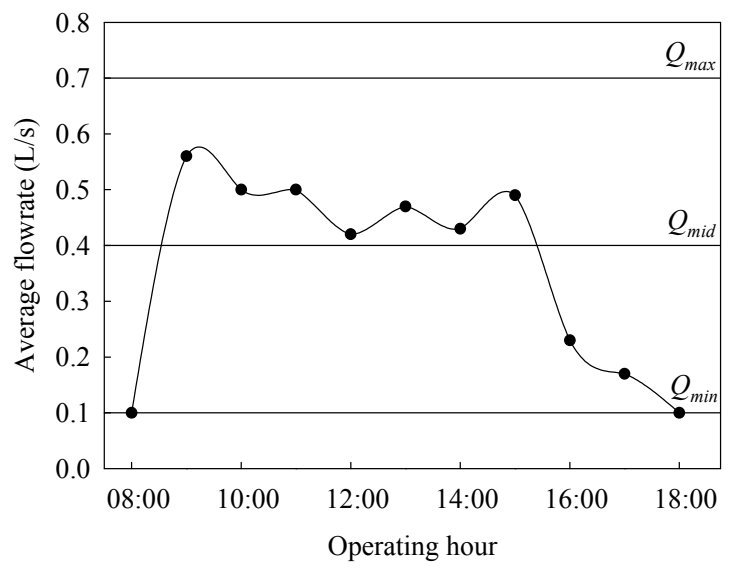

Figure 2: Influent flow rate in grit chamber.

The wastewater receiving tank was designed with a HRT $=35-45$ minutes [9] in order to avoid decomposition of the organic matter, better known as anaerobic degradation [1]. In accordance to the previous wastewater flow rates, the optimum HRT was calculated in 44 minutes which is within the designed specifications. However, the operating wastewater flow rate of the reception tank did not comply with the design criteria since a flooding situation occurred when the wastewater was pumped into the pilot plant. For this particular situation, a by-pass channel had to be designed and implemented for adjusting the wastewater flow rate and reaching the optimum HRT (Figure 5). 


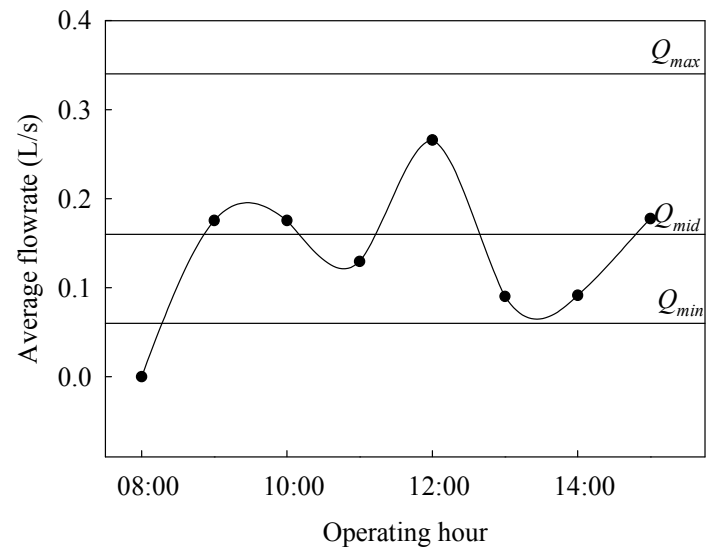

Figure 3: By-passed influent flow rate.

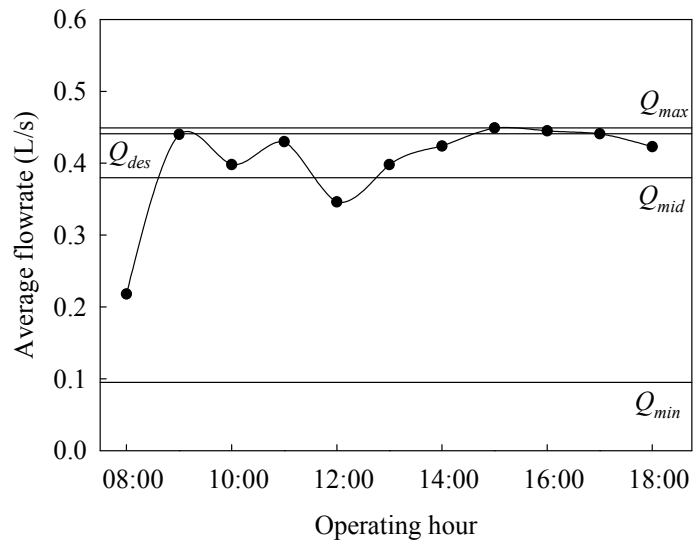

Figure 4: Average flow rate treated in the WWTP.

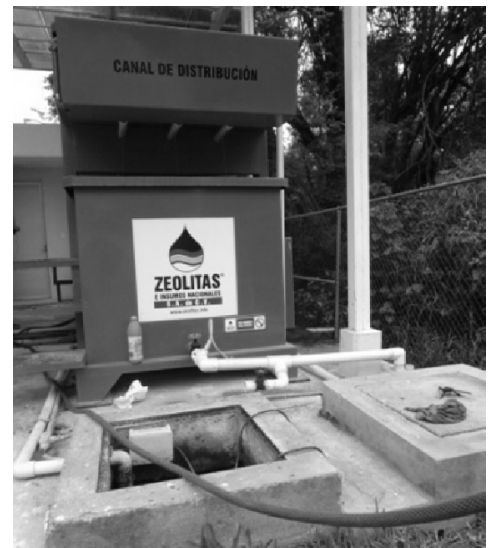

Figure 5: By-pass channel. 
The control and reception units are known as a fast mixing process. In this case, the treatment units are generally built as systems whether channeling modifications exist or not. Special attention must be paid, however, when the HRT exceeds 10 minutes for the wastewater flowing through the system. In this sense, optimum HRT values have been reported to be between 1 and 3 minutes in order to attain an effective mixing process [12].

The hydraulic flocculation system and the settler are designed with a HRT in the range of 10 to 40 minutes and 30 to 120 minutes, respectively [9]. The latter is adjusted as a function of the metallic salts and the results obtained in the treatability tests. For the current study, the pilot plant comprises one unit for the sedimentation-coagulation process having a HRT $=53$ minutes as design specification and 72 minutes under real operating conditions. From this operating standpoint, the sedimentation process became inefficient since the solid particles were dragged down the system. During operation, the sediment was found to be $2-4 \mathrm{~cm}$ thick when the wastewater flow rate velocity exceeded $0.3 \mathrm{~m} / \mathrm{s}$. This condition prompted a new engineering modification. In this respect, the main channeling was left to solely operate the flocculation step and construct, therefore, an external device (coupled to the pilot plant) that works for sedimentation (sludge extraction and separation step). Likewise, the filtration unit was underestimated since a high filtration velocity $\left(<1 \mathrm{~L} / \mathrm{s} / \mathrm{m}^{2}\right)$ was found in comparison with the design specifications $\left(3-4 \mathrm{~L} / \mathrm{s} / \mathrm{m}^{2}\right)$.

According to the measured average wastewater intake $\left(\mathrm{Q}_{\mathrm{a}}=115.2 \mathrm{~m}^{3} / \mathrm{d}\right)$ and inlet wastewater composition $(\mathrm{BOD}=833 \mathrm{ppm}, \mathrm{QOD}=2292 \mathrm{ppm}, \mathrm{TDS}=1250$ $\mathrm{ppm}$ ), the pilot plant should be removing, at least, $96.4 \%$ of the BOD [9]. Under these conditions, however, the maximum and minimum removal efficiency were calculated to be $81.3 \%$ and $21.8 \%$, that is, an average removal efficiency of $51.55 \%$ (Figures 6-8). This was expected since the sedimentation-coagulationflocculation process had a low performance.

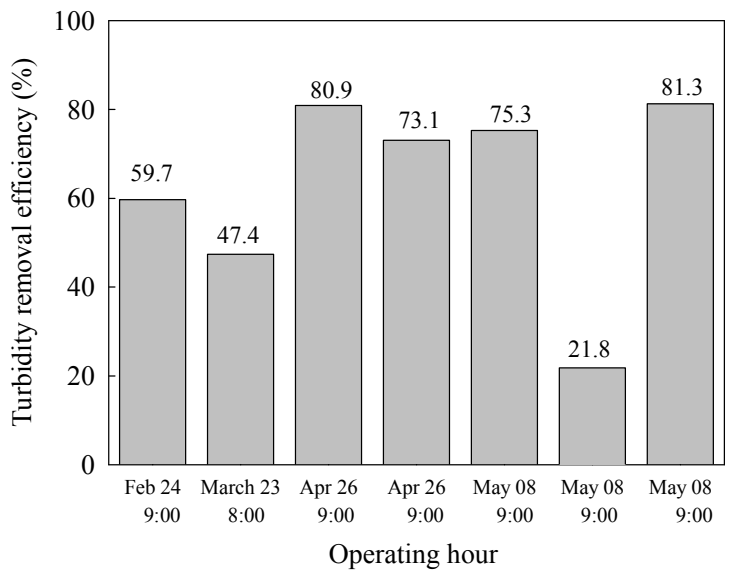

Figure 6: Turbidity removal of the coagulation-flocculation-settling process. 


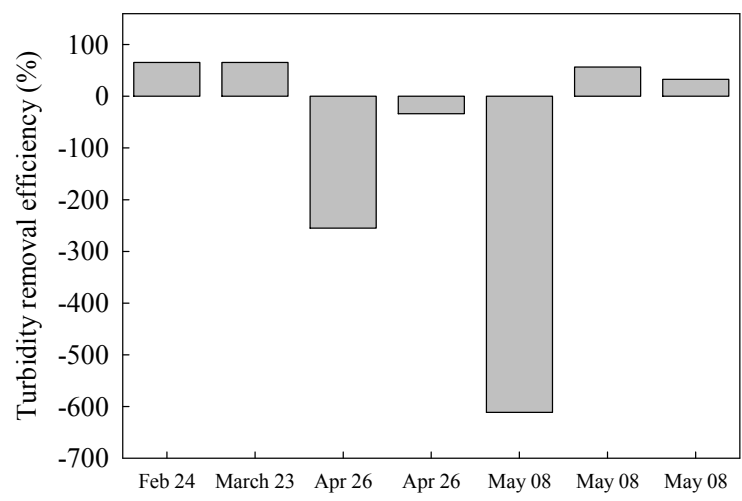

Operating hour

Figure 7: Turbidity removal of the filtration process.

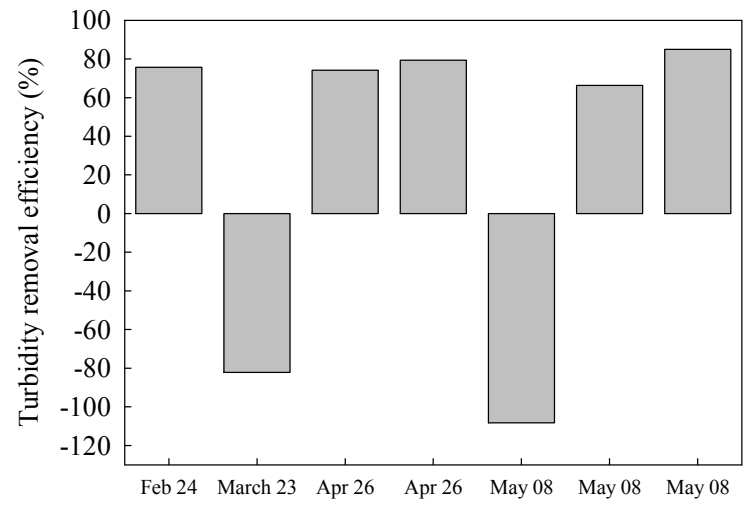

Operating hour

Figure 8: Overall turbidity removal efficiency of the WWTP.

On the other hand, the filtration system has been shown to be the more problematic since either it saturates quickly or the retained material gets loose due to the $\mathrm{pH}$ variation. Hence it becomes evident the need to schedule preventive and corrective maintenance, which must be programmed once the negative efficiencies have been identified in the treatment units. In terms of the operation along the studied period, the pilot plant performed poorly during $28.6 \%$ of the monitoring time. The remaining $71.4 \%$, nevertheless, it operated in a regular manner.

At normal operating conditions, an amount of metallic salts is added to physicochemically treat the wastewater stream in the pilot plant. A dosification process is implemented to daily poor $2500 \mathrm{ppm}$ of $\mathrm{Al}_{2}\left(\mathrm{SO}_{4}\right)_{3}$ and $2500 \mathrm{ppm}$ of $\mathrm{Ca}(\mathrm{OH})_{2}$. Such doses in excess are well known to be ineffective from the 
technical and economical standpoint. In addition, greater amounts of sludge generated by these metallic salts lead to serious ecological affectations at the surroundings of superficial water receptors. Therefore, various treatability tests were proposed to optimize the doses of the metallic salts in the pilot plant.

The main control parameters measured throughout the treatability tests were turbidity, temperature and $\mathrm{pH}$ (Table 2). The first test showed that turbidity concentrations decreased from 124 to $54 \mathrm{NTU}\left(\eta_{I}=54.03 \%\right)$ when using only $60 \mathrm{ppm}$ of $\mathrm{Al}_{2}\left(\mathrm{SO}_{4}\right)_{3}$ (Figure 9). For the second test, a higher removal efficiency

Table 2: $\quad$ Treatability parameters.

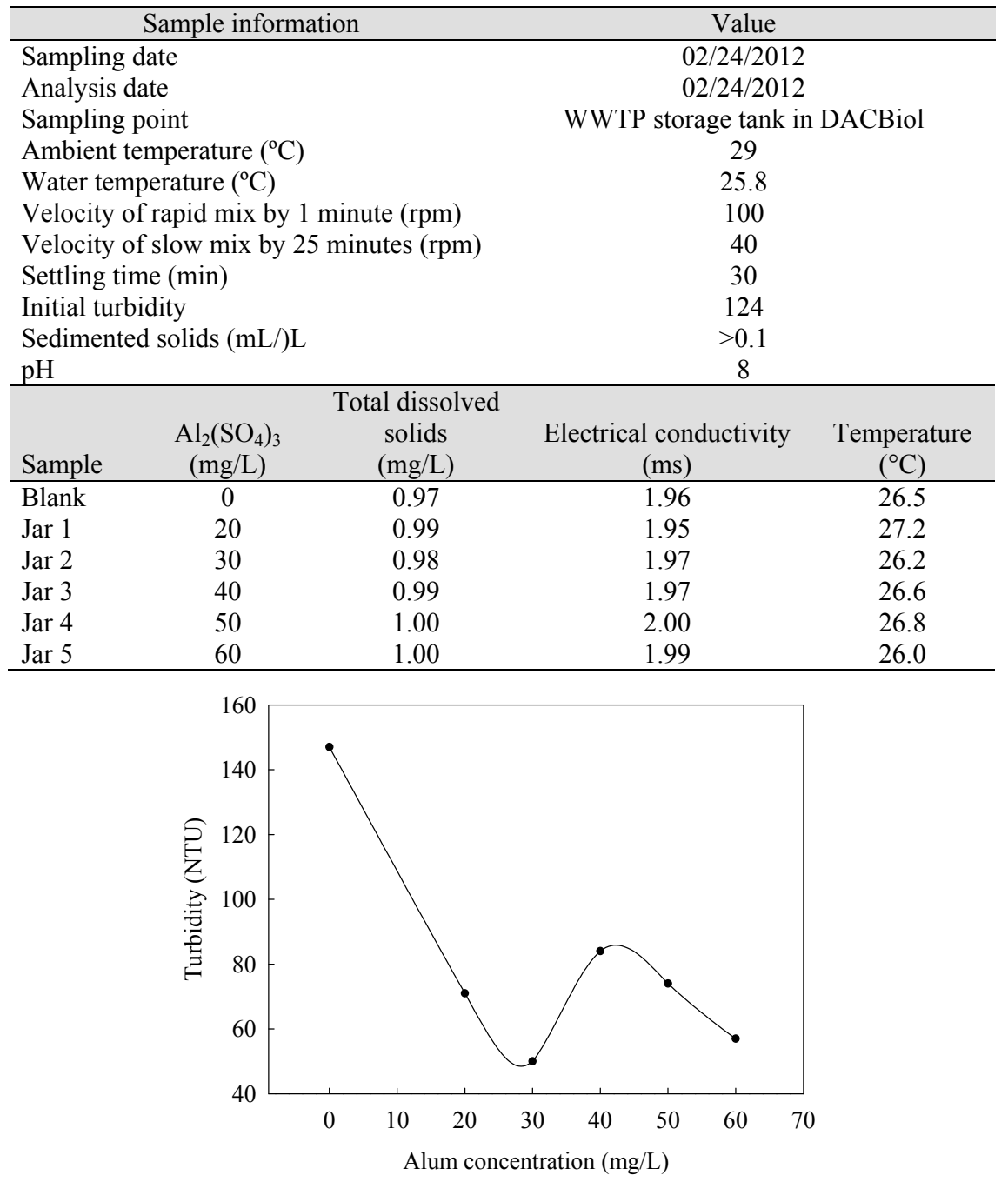

Figure 9: Effect of dosification of alum on final turbidity for jar 1. 
$\left(\eta_{2}=70.48 \%\right)$ was obtained when adding $100 \mathrm{ppm}$ of $\mathrm{Al}_{2}\left(\mathrm{SO}_{4}\right)_{3}$ (Figure 10). Further efficiency improvement $\left(\eta_{3}=91.96 \%\right)$ was observed during the third test when adding $15 \mathrm{mg} / \mathrm{l}$ of $\mathrm{Ca}(\mathrm{OH})_{2}$ and $50 \mathrm{mg} / 1$ of $\mathrm{Al}_{2}\left(\mathrm{SO}_{4}\right)_{3}$ (Figure 11). Finally, the highest removal efficiency $\left(\eta_{4}=95.26 \%\right)$ was attained when adding $10 \mathrm{mg} / \mathrm{l}$ of $\mathrm{Ca}(\mathrm{OH})_{2}$ and $35 \mathrm{mg} / \mathrm{l}$ of $\mathrm{Al}_{2}\left(\mathrm{SO}_{4}\right)_{3}$ in combination with zeolites (Figure 12). With these results, it is clearly evidenced that both metallic salts were overdosed to the wastewater treatment system $(1 \mathrm{~kg}$ each salts $/ 1000 \mathrm{~L}$ wastewater).

The turbidity removal achieved, during the optimization of the pilot plant, is highly significant for water to be used for agricultural irrigation. This variable is considered as a water pollution indicator [13], because it is associated with

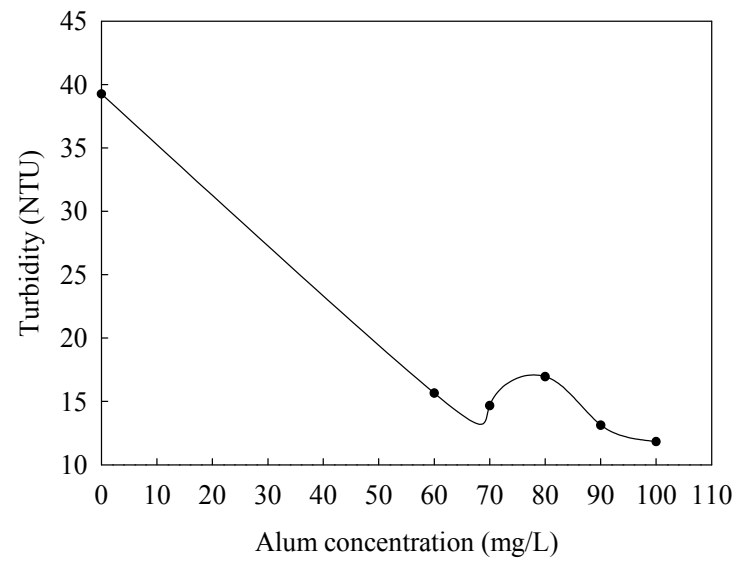

Figure 10: Effect of dosification of alum on final turbidity for jar 2.

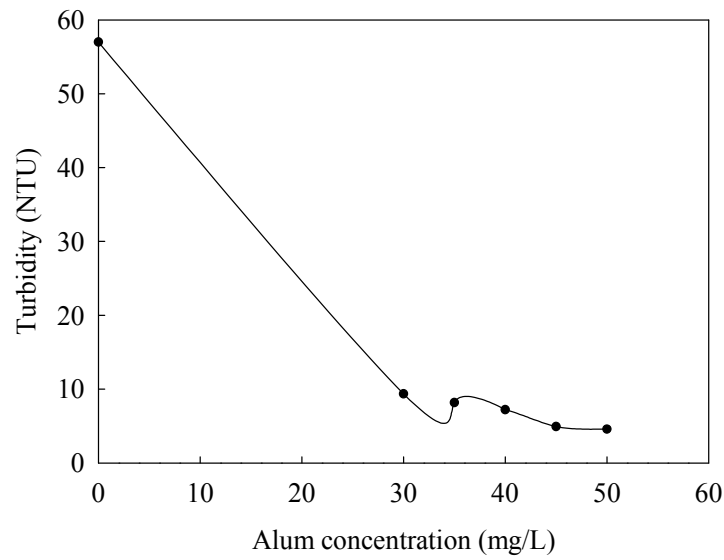

Figure 11: Effect of dosification of alum on final turbidity for jar 3 . 


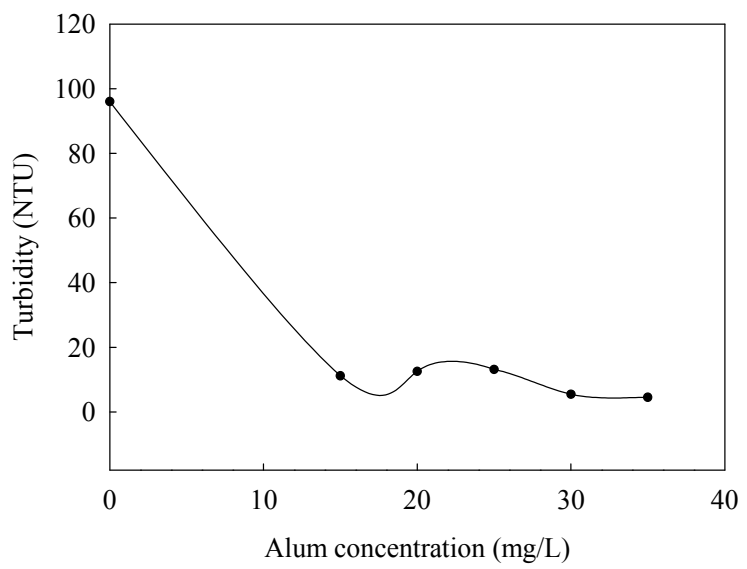

Figure 12: $\quad$ Effect of dosification of alum on final turbidity for jar 4 .

particles that protect pathogenic microorganisms and accumulate toxic substances [14]. Therefore, it may be considered as an indirect microbiological variable, rather than a physical one, since turbidity removal may be associated with removal of pathogens trapped in the sludge [15].

\section{Conclusions}

The combination of metallic salts with zeolites filtration has been demonstrated to attain high removal efficiencies for a pilot-scale wastewater treatment plant. The highest removal efficiency obtained in the pilot plant, in terms of turbidity, was $95.26 \%$ when optimizing the addition of calcium hydroxide and aluminum sulfate. To avoid saturation levels at the zeolites filtration point, the $\mathrm{pH}$ parameter has to be periodically monitored and controlled. The current results suggest that mixing time, time of flocculate formation and sedimentation time play an important role to efficiently operate domestic wastewater treatment systems. Finally, careful operating considerations must be taken into account when applying a given physicochemical treatment referred to the HRT condition and wastewater composition of the treatment plant.

\section{References}

[1] Crites, R., Tchobanoglous, G. (2000) Sistemas de manejo de aguas residuales para núcleos pequeños y descentralizados. Tomos 1, 2 y 3 . Traducido de la primera edición en inglés. Bogotá, Colombia.

[2] Jing, S.R.. Lin Y.F. 2004, Seasonal effect on ammonia nitrogen removal by constructed wetlands treating polluted river water in southern Taiwan. Environmental Pollution 127 (2004), pp. 291-301. 
[3] Reed, S.C.. R.W. Crites. and E.J. Middlebrooks, 1995, Natural Systems for Waste Management and Treatment-Second Edition, McGraw Hill Co. New York, NY.

[4] Foresti E., Zaiat M., Vallero M. (2006), Anaerobic processes as the core technology for sustainable domestic wastewater treatment: consolidated applications, new trends, perspectives and challenges. pp 3-19.

[5] Metcalf and Eddy. (1996) Ingeniería de aguas residuales. Tratamiento, vertido y reutilización, Vol. I y II. Tercera edición, Edit. McGraw Hill, México, D.F.

[6] Norma Oficial Mexicana NOM-001-ECOL-1996, que establece los límites máximos permisibles de contaminantes en las descargas de aguas residuales en aguas y bienes nacionales. Normas Técnicas Mexicanas de Aguas Residuales en México. Diario Oficial de la Federación (30/04/1997).

[7] López-Ocaña G. (2009) Manual de operación y mantenimiento de la planta potabilizadora Huapinol. Proyecto ejecutivo del sistema integral de agua potable del Corredor Huapinol, Playas del Rosario, Cacao, Municipios de Centro y Jalapa, Tabasco. Contrato SAPAET-APASZU010/2009.

[8] Sotelo G. (2005) Hidráulica General I, Fundamentos. México, D.F. p. 561.

[9] CONAGUA (2007) Comisión Nacional del Agua. Manual de agua potable, alcantarillado y saneamiento. Gerencia de proyectos de agua potable, alcantarillado y saneamiento. México. D.F.

[10] Hach Company (1997) World Headquarters. DR/2010 procedures manual. Loveland, Colorado. 872 p.

[11] López-Ocaña G., Padrón-López R.M., Torres-Balcázar C.A. (2012) Evaluación y optimización del sistema de tratamiento de aguas residuales domésticas de la DACBIOL. Primer Reporte Técnico. Universidad Juárez Autónoma de Tabasco.

[12] Arboleda Valencia J. (2000). Teoría y práctica de la purificación del agua. Asociación colombiana de ingeniería sanitaria. Tomo 1 y Tomo 2 Editorial McGraw Hill, México.

[13] Corbitt, R.A. (1990) Wastewater disposal. In: Standard Handbook of Environmental Engineering. McGraw Hill. Willard, Ohio. Chapter 6. 273 p.

[14] De Zuane, J.P.E. (1997) Handbook of Drinking Water Quality. 2nd Ed. Von Nostrand Reinhold Publishers. New York N.Y. 575 p.

[15] Rechcigl, J.E. (1995) Soil Amendments and Environmental Quality. Agriculture and Environmental Series. Lewis Publishers. Ona, Florida. $505 \mathrm{p}$. 